\title{
Biomonitoring of Heavy Metals Level in Wetland Plants of Lagos Lagoon, Nigeria
}

\author{
*ADESUYI, AA; NJOKU, KL; AKINOLA, MO; JOLAOSO, AO
}

Environmental Biology Research Unit, Cell Biology and Genetics Department, University of Lagos, P.O. Box 132, Akoka, Lagos, Nigeria *Corresponding email: biologistalex@gmail.com; adeola.adesuyi@yahoo.com

\begin{abstract}
The purpose of this research was to monitor the distribution of $\mathrm{Cd}, \mathrm{Cr}, \mathrm{Cu}, \mathrm{Ni}, \mathrm{Pb}$ and $\mathrm{Zn}$ in plants of Lagos lagoon wetlands in Nigeria. Water, soil and dominant plants were collected from 46 sampling points for a period of 1 year and analysed using ICP-AES. The order of heavy metals presence in soil samples was as follow: $\mathrm{Zn}>\mathrm{Cr}>\mathrm{Cu}>\mathrm{Pb}>\mathrm{Cd}>\mathrm{Ni}$. The $\mathrm{Zn}$ concentration was the highest whereas the lowest concentration was Ni. All water samples showed varying degrees of contamination across all the sampling points in these wetlands. A greater percentage of all metals concentration for $\mathrm{Pb}, \mathrm{Cd}, \mathrm{Cr}$ and $\mathrm{Ni}$ were higher than the permissible limit set by World Health Organisation. $\mathrm{Pb}$ ranged from $0.01 \pm 0.00$ to $0.91 \pm 0.04 \mathrm{mg} / \mathrm{L}, \mathrm{Cd}$ from $0.01 \pm 0.00$ to $0.31 \pm 0.02 \mathrm{mg} / \mathrm{L}, \mathrm{Cr}$ from $0.05 \pm 0.00$ to $1.15 \pm 0.01 \mathrm{mg} / \mathrm{L}$, $\mathrm{Ni}$ from $0.01 \pm 0.00$ to $0.52 \pm 0.03$, Cu from $0.21 \pm 0.01$ to $1.11 \pm 0.01 \mathrm{mg} / \mathrm{L}$ and $\mathrm{Zn}$ ranged from $0.15 \pm 0.00$ to $10.28 \pm 0.02 \mathrm{mg} / \mathrm{L}$. The median values of each metal that the shoots and roots of individual plants accumulated metals in the order: $\mathrm{Zn}>\mathrm{Cu}>\mathrm{Pb}>\mathrm{Cr}>\mathrm{Ni}>\mathrm{Cd}$. Ipomea aquatica had the highest concentration of $\mathrm{Pb}$ in its shoot $(1.12 \mathrm{mg} / \mathrm{kg})$ while Ludwigia adscendens had the least $(1.12 \mathrm{mg} / \mathrm{kg})$ in its shoot. $\mathrm{Pb}$ level in the roots was highest in Eichonia crassipes $(5.69 \mathrm{mg} / \mathrm{kg})$. The highest level of $\mathrm{Cr}$ in shoot $(2.23 \mathrm{mg} / \mathrm{kg})$ and root $(5.41 \mathrm{mg} / \mathrm{kg})$ was observed in Commelina benghalensis while $\mathrm{Cr}$ concentration is lowest in the shoot $(0.04 \mathrm{mg} / \mathrm{kg})$ and root $(0.18 \mathrm{mg} / \mathrm{kg})$ of Althernathera philoxerrides. Ludwigia adscendens had the lowest concentration of $\mathrm{Ni}$ in its root $(0.01 \mathrm{mg} / \mathrm{kg})$. The highest shoot concentration of $\mathrm{Cu}(4.21 \mathrm{mg} / \mathrm{kg})$ was observed in Eichonia crassipes while Ipomea aquatica had the lowest concentration in its shoot $(0.23 \mathrm{mg} / \mathrm{kg})$. Paspalum vaginatum's root had the highest $\mathrm{Cu}$ concentration $(12.32 \mathrm{mg} / \mathrm{kg})$ while lowest concentration of $\mathrm{Cu}$ was observed in the root of Sagittaria sagittifolia $(0.69 \mathrm{mg} / \mathrm{kg})$. Transfer factors for most of the plants species were less than 1, indicating that metals accumulated by these plants were largely retained in the roots. A. philoxerrides had translocation factor greater than one for $\mathrm{Ni}$ (10.30), while for $\mathrm{Cr}$ was 1.25 and 1.40. This present findings indicate that, despite ecological similarities, the different plant species tend to respond differently to exposure to heavy metals and also in their ability to accumulate the various metals. Thus, heavy metals sequestration from the soil to these plants characterized them as metals pollution indicators.
\end{abstract}

\section{DOI: https://dx.doi.org/10.4314/jasem.v22i9.22}

Copyright: Copyright $(92018$ Adesuyi et al. This is an open access article distributed under the Creative Commons Attribution License (CCL), which permits unrestricted use, distribution, and reproduction in any medium, provided the original work is properly cited.

Dates: Received: 10 May 2018; Revised: 22 August 2018; Accepted: 01 September 2018

Keywords: wetland plants, heavy metals, biomonitoring, bioaccumulation capacity, translocation factor

Nigeria is richly endowed with large numbers of wetlands ecosystem, and the Lagos lagoon has been identified as one of the fourteen major wetland belts in the country (Oyebande, et al., 2003; Asibor, 2009). Wetlands are very important subsystem of the general ecosystem as they play vital roles in the sustenance of both surface and ground water resources of the earth. The importance of any wetland is sited within its functions and values. Notably, the functions of wetlands include flood control, groundwater recharge, coastal protection, sediment traps, atmospheric equilibrium and waste treatments. As well as providing nurseries for aquatic life and habitat for upland mammals (Ramsar Convention, 2007; Chidi and Ominigbo, 2010). As an ecosystem, wetlands are valued for their contribution to ecological balance and biodiversity. They also aid in food production especially in the cultivation of rice and vegetables. Rapid urbanization and industrialization have led to increase in pollution from landfill leachates, industrial effluents, vehicular emissions, fossil fuels, fertilizer erosion from agricultural run-off, herbicides and pesticides, sewage and municipal wastes. All these contributed to the accumulation of pollutants in nearby aquatic systems (Adesuyi et al., 2015a; Adesuyi et al., 2016). Among the worst environmental contaminants are the heavy metals (Njoku et al., 2013). They are serious pollutants due to their toxicity, persistence in natural conditions and ability to be incorporated into food chains (Akinola et al., 2008; Adesuyi et al., $2015 b)$. Some of these metals includes lead $(\mathrm{Pb})$, cadmium $(\mathrm{Cd})$ copper $(\mathrm{Cu})$, zinc $(\mathrm{Zn})$ nickel $(\mathrm{Ni})$ and chromium (Cr). For an area to be designated a wetland, it must possess water, wetland plants and wetland soils (Asibor, 2009). Wetlands as an ecosystem is characterized by the presence of plants that are adapted to life in the soil formed under saturated conditions (Mitsch and Gosselink, 1993). Some of these plants include Alternanthera philoxeroides, Commelina benghalensis, Eichhornia crassipes, Enhydra 
fluctuans, Ipomoea aquatica, Ludwigia adscendens, Sagittaria sagittifolia Pistia stratiotes and the sedges. These plants enable the direct assessment of the response of wetland vegetation to changes in aquatic discharge. In the past few decades, an increasing use of higher plant leaves as biomonitors for heavy metal pollution has been on the increase especially in sensitive and urban areas (Yasar et al., 2010; Akguc et al., 2010). A study by Ghavzan et al., (2006) demonstrated that Pistia stratiotes was associated with high pollution rates in water bodies, while Niaz and Rasul (1998) showed that Pistia stratiotes and Eichhornia crassipes could be used as biological indicators in wetland habitats. A good biomonitor will indicate the presence of the pollutant and also provide additional information about the quantity and intensity of the exposure (Wolterbeek, 2002). Metal uptake by vegetation can be element specific, plant species specific and plant tissue specific (Du Laing et al., 2009; Matache et al., 2013). Rai et al. (1995) identified Ceratophyllum demersum as a hyperaccumulator species for cadmium. Salvinia minima was discovered to have the capacity to remove lead from aqueous solutions (Estrella-Gómez et al., 2009), whilst Cladophora sp. is able to hyperaccumulate arsenic (Pell et al., 2013). The capacity of plants to hyperaccumulate trace elements is influenced by the presence of humic substances or other chelating substances, temperature and salinity (Fritioff et al., 2005; Matache et al., 2013). Knowledge about the bioaccumulation of heavy metals in wetlands plant species in Lagos lagoon wetlands is limited. Hence, the aims of this paper are to investigate the amount of heavy metals in dominant plants species collected from Lagos lagoon wetlands; and to assess the opportunity of using these aforementioned plant species as indicators of the aquatic ecosystems pollution level with heavy metals and also their feasibility for phytoremediation.

\section{MATERIALS AND METHODS}

Study Area: The Lagos lagoon wetlands forms part of an intricate system of water ways made up of lagoons and creeks that are found along the coast line of Nigeria, Benin Republic. It is located between longitudes $3^{\circ} 23^{\prime}$ and $3^{\circ} 40^{\prime} \mathrm{E}$, and latitudes $6^{\circ} 22^{\prime}$ and $6^{\circ} 38^{\prime} \mathrm{N}$ (Figure 1). Lagos lagoon is the largest of the four lagoon systems, mainly of the Gulf of Guinea, 2 covering an area of $257.49 \mathrm{~km}^{2}$ (Philips et al., 2012). The area surrounding the Lagos lagoon is probably the most urbanized and industrialized in Nigeria (Okoye et al., 1991). This urban expansion in an unsystematic manner has had serious repercussions on the environmental quality of many parts of the wetlands (Obiefuna et al., 2013).

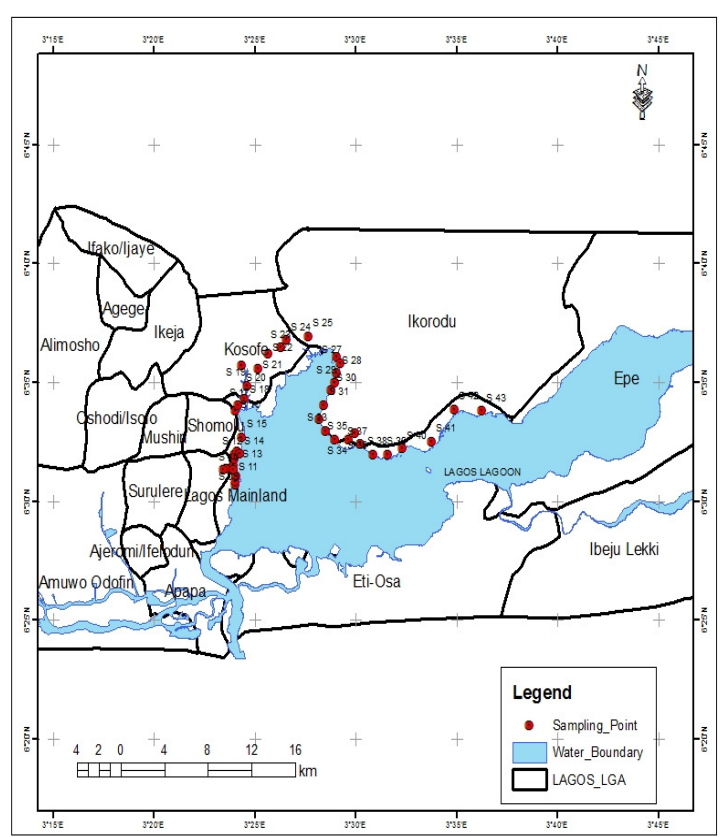

Fig 1: Lagos Lagoon showing the Study areas

Sampling and data collection: The samples were collected in these wetlands for a year (June 2015 and May 2016) during different vegetation seasons from 46 sampling points, in order to obtain accurate data set. For each location, a sample was composed of three plants of the same species collected and pooled into a uniform sample. Thus the water samples were collected at the depth of $0.5 \mathrm{~m}$ below the surface and stored in $500 \mathrm{ml}$ polyethylene bottles precleaned with deionized water and rinsed with the sample to be collected from different sites. The soil samples used in this study were collected at each site of plant collection from $0-10 \mathrm{~cm}$ depth and the exact location was obtained using Garmin GPS and coordinates recorded. Plant samples were randomly collected and labeled, put in individual polythene bags and brought to the laboratory. They were identified and authenticated in the Herbarium unit, Department of Botany, University of Lagos, Lagos.

Sample preparation and chemical analyses: The roots and the aboveground parts were separated and stored in the zipped polyethylene bags, respectively. The samples were washed thoroughly with tap water and rinsed with deionized water, then dried at $70{ }^{\circ} \mathrm{C}$ for 24 $\mathrm{h}$ in an oven. After the measurement of dry weights, the samples were ground into fine powder in an agate mortar. Precise weigh of each sample $(0.2000 \mathrm{~g})$ were used to prepare the solution of digestion reaction. A mixture of concentrated $\mathrm{HNO}_{3}(2 \mathrm{ml})$ at $65 \%$ and $\mathrm{H}_{2} \mathrm{O}_{2}$ $(1 \mathrm{ml})$ at $30 \%$ was used for digestion reaction. After cooling to the room temperature, the residue was 
diluted with deionized water to $10 \mathrm{ml}$ and analyzed for metals by ICP-AES (Zhang et al., 2010).

The water samples were filtered through $0.45 \mu \mathrm{m}$ Millipore filters and acidified to $\mathrm{pH}<2$ using concentrated nitric acid and then stored in the dark at $4{ }^{0} \mathrm{C}$. The concentrations of heavy metals were measured by inductively coupled plasma-atomic emission spectrometry (ICP-AES). All of soil samples were air-dried at room temperature immediately after collection and sieved through a 2-mm nylon sieve to remove coarse debris. For each sample, $30 \mathrm{~g}$ sub- sample of soils was ground with an agate mortar until all particles passed a 100-mesh nylon sieve. A 0.1000 $\mathrm{g}$ sub-sample of dried and homogenized soil was accurately weighed and digested with $2 \mathrm{ml} \mathrm{HNO}_{3}, 1$ $\mathrm{ml} \mathrm{HClO}_{4}$ and $5 \mathrm{ml} \mathrm{HF}$ at a temperature of $90 \pm 190{ }^{\circ} \mathrm{C}$ for $16 \mathrm{~h}$. The residue was then dissolved in $2 \mathrm{ml}$ of 4 $\mathrm{mol} / \mathrm{L} \mathrm{HCl}$ and diluted to $10 \mathrm{ml}$ with deionized water and analyzed for a number of heavy metals $(\mathrm{Pb}, \mathrm{Cd}$, $\mathrm{Cr}, \mathrm{Ni}, \mathrm{Cu}$, and $\mathrm{Zn}$ ) by inductively coupled plasmaatomic emission spectrometry (ICP-AES) (Zhang et al., 2010).

Bioaccumulation factor $(B A F)$ and Translocation factor $(T F)$ : BAF of the heavy metal was calculated by: $B A F=\frac{\text { level of metal in shoot }(\mathrm{mg} / \mathrm{kg})}{\text { level of metal in growing medium }(\mathrm{mg} / \mathrm{kg})}-($ Rezvani and Zaefarian, 2011$)$

Translocation from shoot to root was measured by TF which is given below:

$T F=\frac{\text { Level of metal in shoot }}{\text { level of metal in root }}-($ Rezvani and Zaefarian, 2011)

Statistical analysis: Statistical analysis of data was performed using GraphPad 7.0. Nonparametric test was used to determine any significant difference in metal contents among different sample sites at the level of $\mathrm{p} \leq 0.05$. Correlations among metal concentrations in the water, soils and plants samples were evaluated using Pearson correlation coefficients.

\section{RESULTS AND DISCUSSIONS}

Mean heavy metals in sediments and soils of wetlands: The level of heavy metals in soils obtained from the wetlands is presented in table 1 . The concentrations of metal displayed a wide variation as reflected by the large standard deviation values and high coefficient of variation, suggesting the spatial variation of metals is obvious (Tam et al., 2010). Also, analysis of variance revealed a significant $(\mathrm{p}<0.05)$ variation in the spatial distribution of all the heavy metals of concentrations which is an indication of anthropogenic influence and the extent of metal pollution in the Lagos lagoon wetland soils. The order of heavy metals presence in soil samples was as follow: $\mathrm{Zn}>\mathrm{Cr}>\mathrm{Cu}>\mathrm{Pb}>\mathrm{Cd}>\mathrm{Ni}$. The $\mathrm{Zn}$ concentration was the highest whereas the lowest concentration was Ni. This is in agreement with earlier studies by Gupta et al. (2009) and Zhang et al. (2010) that $\mathrm{Zn}$ was maximally concentrated in riverine sediments collected from Ganges at Allahabad and soils from riparian wetlands in the Pearl River Estuary, South China. $\mathrm{Pb}$ concentration in the soils ranged from 0.05 to $7.89 \mathrm{mg} / \mathrm{kg}$ with coefficient of variation of $108.22 \%$. The mean concentrations of $\mathrm{Pb}$ were all below the WHO/FAO (2001) permissible limit of $50.00 \mathrm{mg} / \mathrm{kg}$ for soils. The major sources of $\mathrm{Pb}$ in the wetlands soils might be attributed to industrial waste water discharge, pesticides, and fertilizer impurities, emissions from mining and smelting operations and atmospheric fallout from the combustion of fossil fuels. Typical mean $\mathrm{Pb}$ concentration for surface soils worldwide is $32 \mathrm{mg} / \mathrm{kg}$ and ranges from 10 to $67 \mathrm{mg} / \mathrm{kg}$ (Kabata-Pendias and Pendias, 2001). Cd ranged from 0.00 to $2.01 \mathrm{mg} / \mathrm{kg}$ with the highest coefficient of variation of $143.30 \%$. The mean concentrations of $\mathrm{Cd}$ recorded at all sites were below the WHO/FAO (2001) permissible limit of $3 \mathrm{mg} / \mathrm{kg}$ for soils. Cadmium is very much connected with nonresidual fractions of heavy metals and thus makes them mobile and potentially bio-available for uptake by plants (Zhang et al., 2009). A typical characteristic of flooded wetland soils is the development of anoxic, reduced conditions. This results in accumulation of organic matter in the soil, formation of metal sulfides, and commonly near-neutral $\mathrm{pH}$. $\mathrm{Cd}$ can remain immobilized in wetland soils under these conditions (Jacob et al., 2013). Another important source of Cd is the use of mineral phosphate fertilizer, which typically contains high $\mathrm{Zn}$ and $\mathrm{Cd}$ concentrations in addition to other elements. Phosphate fertilizer application can directly increase both the $\mathrm{Pb}$ and $\mathrm{Cd}$ concentrations in the soil solution (Lambert et al., 2007). Wetland soils are also known to show different biogeochemical behavior when compared with dryland soils. $\mathrm{Cr}$ ranged from 0.01 to $6.53 \mathrm{mg} / \mathrm{kg}$ with coefficient of variation of $122.58 \%$. The high concentration of $\mathrm{Cr}$ recorded in this wetland soils could be as a result of the open dumping of municipal and e-wastes, and effluent discharge at some of the sites. The mean concentrations of $\mathrm{Cr}$ recorded at all sites were below 
the WHO/FAO (2001) permissible limit. The occurrence of $\mathrm{Cr}$ in soils could be due to disposal of waste consisting of lead-chromium batteries, coloured polythene bags, discarded plastic materials and empty paint containers (Amos-Tautua et al., 2014). Chromium mobility in wetlands depends on sorption characteristics of the soil, including clay content, iron oxide content, and the amount of organic matter present, and they are transported by surface runoff to surface waters in its soluble or precipitated form (Wuana and Okieimen, 2011). Ni has the lowest concentration with the value range of 0.01 to 1.10 $\mathrm{mg} / \mathrm{kg}$, with a coefficient of variation of $101.29 \%$. The mean concentrations of $\mathrm{Ni}$ recorded at the various sites were below the WHO/FAO (2001) permissible limit of $50 \mathrm{mg} / \mathrm{kg}$ for soils. Nickel is an element that occurs in the environment only at very low levels and is essential in small doses, but it can be dangerous when the maximum tolerable amounts are exceeded (Wuana and Okieimen, 2011).The major sources of nickel contamination in the soil are metal plating industries, combustion of fossil fuels, and nickel mining and electroplating (Khodadoust et al., 2004). Cu ranged from 0.46 to $3.55 \mathrm{mg} / \mathrm{kg}$ with a coefficient of variation of $53.09 \%$ which is the lowest of the heavy metals assessed. The mean concentrations of copper recorded were below the WHO/FAO (2001) permissible limit of $100 \mathrm{mg} / \mathrm{kg}$ for soils. $\mathrm{Zn}$ has the highest concentration value that ranged from 0.10 to 15.06 $\mathrm{mg} / \mathrm{kg}$ with a coefficient of variation $132.15 \%$. There was a high variation in the spatial distribution of $\mathrm{Zn}$. The variation in concentration level of Zinc in these soils showed the impact of pollution from anthropogenic activities rather than lithogenic one. However, the maximum mean concentration of $\mathrm{Zn}$ recorded was lower than the WHO/FAO (2001) permissible limit of $300.00 \mathrm{mg} / \mathrm{kg}$ for soils. $\mathrm{Cu}$ and $\mathrm{Zn}$ are two important essential elements for plants, microorganisms, animals, and humans. The connection between soil and water contamination and metal uptake by plants is determined by many chemical and physical soil factors as well as the physiological properties of the plants. Soils contaminated with trace metals may pose both direct and indirect threats: direct, through negative effects of metals on crop growth and yield, and indirect, by entering the human food chain with a potentially negative impact on human health (Wuana and Okieimen, 2011).

\begin{tabular}{|c|c|c|c|c|c|c|c|}
\hline $\mathbf{S} / \mathbf{N}$ & $\begin{array}{l}\text { Sampling } \\
\text { points }\end{array}$ & $\mathbf{P b}$ & Cd & $\mathrm{Cr}$ & $\mathbf{N i}$ & $\mathbf{C u}$ & $\mathbf{Z n}$ \\
\hline 1 & S 01 & $1.25 \pm 0.00$ & $0.01 \pm 0.00$ & $1.09 \pm 0.02$ & $0.01 \pm 0.00$ & $2.55 \pm 0.05$ & $4.15 \pm 0.05$ \\
\hline 2 & S 02 & $1.59 \pm 0.02$ & $0.01 \pm 0.00$ & $0.50 \pm 0.05$ & $0.01 \pm 0.00$ & $3.00 \pm 0.00$ & $1.09 \pm 0.02$ \\
\hline 3 & S 03 & $1.05 \pm 0.03$ & $0.01 \pm 0.00$ & $0.41 \pm 0.06$ & $0.01 \pm 0.00$ & $2.75 \pm 0.03$ & $1.06 \pm 0.00$ \\
\hline 4 & S 04 & $0.95 \pm 0.01$ & $0.01 \pm 0.00$ & $0.13 \pm 0.01$ & $0.01 \pm 0.00$ & $3.1 \pm 0.00$ & $0.78 \pm 0.06$ \\
\hline 5 & S 05 & $0.76 \pm 0.01$ & $0.01 \pm 0.00$ & $0.17 \pm 0.02$ & $0.03 \pm 0.00$ & $3.55 \pm 0.05$ & $0.96 \pm 0.02$ \\
\hline 6 & S 06 & $0.05 \pm 0.02$ & $0.12 \pm 0.02$ & $0.89 \pm 0.06$ & $0.05 \pm 0.00$ & $1.60 \pm 0.06$ & $0.79 \pm 0.09$ \\
\hline 7 & S 07 & $0.12 \pm 0.02$ & $0.46 \pm 0.34$ & $0.67 \pm 0.07$ & $0.19 \pm 0.03$ & $1.57 \pm 0.05$ & $0.88 \pm 0.07$ \\
\hline 8 & S 08 & $0.59 \pm 0.02$ & $0.06 \pm 0.01$ & $0.54 \pm 0.04$ & $0.10 \pm 0.00$ & $1.26 \pm 0.00$ & $0.10 \pm 0.00$ \\
\hline 9 & S 09 & $0.42 \pm 0.01$ & $0.03 \pm 0.01$ & $0.47 \pm 0.07$ & $0.07 \pm 0.00$ & $1.55 \pm 0.05$ & $1.01 \pm 0.01$ \\
\hline 10 & S 10 & $0.34 \pm 0.04$ & $0.51 \pm 0.40$ & $0.56 \pm 0.04$ & $0.17 \pm 0.00$ & $1.85 \pm 0.04$ & $2.57 \pm 0.10$ \\
\hline 11 & S 11 & $2.15 \pm 0.01$ & $0.01 \pm 0.00$ & $1.23 \pm 0.02$ & $0.20 \pm 0.03$ & $0.96 \pm 0.03$ & $2.56 \pm 0.04$ \\
\hline 12 & S 12 & $1.96 \pm 0.02$ & $0.03 \pm 0.00$ & $3.91 \pm 0.08$ & $0.32 \pm 0.03$ & $0.56 \pm 0.06$ & $8.34 \pm 0.04$ \\
\hline 13 & S 13 & $1.89 \pm 0.01$ & $0.01 \pm 0.00$ & $1.17 \pm 0.02$ & $0.67 \pm 0.03$ & $0.89 \pm 0.06$ & $1.45 \pm 0.05$ \\
\hline 14 & S 14 & $1.82 \pm 0.03$ & $0.01 \pm 0.00$ & $1.05 \pm 0.00$ & $0.54 \pm 0.10$ & $0.46 \pm 0.04$ & $4.89 \pm 0.04$ \\
\hline 15 & S 15 & $2.23 \pm 0.01$ & $0.10 \pm 0.00$ & $4.67 \pm 0.03$ & $0.65 \pm 0.00$ & $0.89 \pm 0.07$ & $2.67 \pm 0.05$ \\
\hline 16 & S 16 & $0.71 \pm 0.01$ & $0.20 \pm 0.02$ & $0.34 \pm 0.02$ & $0.05 \pm 0.00$ & $0.87 \pm 0.02$ & $1.45 \pm 0.03$ \\
\hline 17 & S 17 & $0.53 \pm 0.00$ & $0.15 \pm 0.00$ & $6.53 \pm 0.03$ & $0.01 \pm 0.00$ & $1.65 \pm 0.01$ & $1.01 \pm 0.00$ \\
\hline 18 & S 18 & $0.99 \pm 0.00$ & $0.18 \pm 0.00$ & $3.90 \pm 0.09$ & $0.03 \pm 0.00$ & $1.09 \pm 0.00$ & $0.75 \pm 0.10$ \\
\hline 19 & S 19 & $0.56 \pm 0.02$ & $0.27 \pm 0.00$ & $4.05 \pm 0.03$ & $0.01 \pm 0.00$ & $1.19 \pm 0.02$ & $0.34 \pm 0.02$ \\
\hline 20 & S 20 & $1.65 \pm 0.03$ & $0.29 \pm 0.03$ & $0.34 \pm 0.02$ & $0.15 \pm 0.03$ & $1.54 \pm 0.04$ & $0.48 \pm 0.07$ \\
\hline 21 & S 21 & $7.89 \pm 0.01$ & $1.56 \pm 0.04$ & $6.53 \pm 0.03$ & $1.10 \pm 0.00$ & $3.20 \pm 0.00$ & $15.06 \pm 0.03$ \\
\hline 22 & S 22 & $7.45 \pm 0.01$ & $1.99 \pm 0.00$ & $3.90 \pm 0.09$ & $0.89 \pm 0.09$ & $2.95 \pm 0.04$ & $3.66 \pm 0.06$ \\
\hline 23 & S 23 & $3.62 \pm 0.02$ & $2.01 \pm 0.00$ & $4.05 \pm 0.03$ & $1.05 \pm 0.00$ & $2.85 \pm 0.05$ & $2.09 \pm 0.02$ \\
\hline 24 & S 24 & $2.99 \pm 0.00$ & $1.55 \pm 0.00$ & $2.96 \pm 0.03$ & $0.85 \pm 0.05$ & $1.55 \pm 0.03$ & $1.26 \pm 0.04$ \\
\hline 25 & S 25 & $3.09 \pm 0.03$ & $0.81 \pm 0.00$ & $0.95 \pm 0.03$ & $0.94 \pm 0.04$ & $2.20 \pm 0.00$ & $2.58 \pm 0.08$ \\
\hline 26 & S 26 & $1.07 \pm 0.04$ & $0.56 \pm 0.06$ & $0.56 \pm 0.04$ & $0.92 \pm 0.04$ & $0.89 \pm 0.08$ & $1.45 \pm 0.03$ \\
\hline 27 & S 27 & $0.95 \pm 0.02$ & $0.4 \pm 0.00$ & $0.67 \pm 0.07$ & $0.62 \pm 0.04$ & $0.97 \pm 0.02$ & $0.87 \pm 0.06$ \\
\hline 28 & S 28 & $0.88 \pm 0.03$ & $0.19 \pm 0.00$ & $0.59 \pm 0.10$ & $0.52 \pm 0.00$ & $1.05 \pm 0.00$ & $0.67 \pm 0.10$ \\
\hline 29 & S 29 & $0.65 \pm 0.01$ & $0.36 \pm 0.00$ & $0.66 \pm 0.06$ & $0.44 \pm 0.04$ & $0.91 \pm 0.06$ & $0.78 \pm 0.05$ \\
\hline 30 & S 30 & $0.95 \pm 0.02$ & $0.4 \pm 0.00$ & $0.93 \pm 0.05$ & $0.31 \pm 0.00$ & $1.10 \pm 0.01$ & $1.19 \pm 0.02$ \\
\hline \multirow{2}{*}{\multicolumn{2}{|c|}{ WHO/FAO (2001) }} & 50.00 & 3.00 & - & 50.00 & 100.00 & 300.00 \\
\hline & & 300.00 & 3.00 & 150.00 & 75.00 & 140.00 & 300.00 \\
\hline
\end{tabular}


Heavy metals in surface water: Table 2 summarizes the total mean concentrations and standard error of mean of $\mathrm{Pb}, \mathrm{Cd}, \mathrm{Cr}, \mathrm{Ni}, \mathrm{Cu}$ and $\mathrm{Zn}(\mathrm{mg} / \mathrm{L})$ in water from the wetlands of Lagos lagoon. All metals showed varying degrees of contamination across all the sampling points in these wetlands. A greater percentage of all metals $(\mathrm{Pb}, \mathrm{Cd}, \mathrm{Cr}$ and $\mathrm{Ni}$ ) were higher than the permissible limit set by WHO (2011) and NIS (2007) except $\mathrm{Cu}$ and $\mathrm{Zn}$. This clearly reflects the influence of the urbanization and advancement in industrialization of Lagos on the wetlands environments. Analysis of variance of metals in surface water for all sampling points showed no significant differences $(\mathrm{p}>0.05)$.

Table 2: Mean heavy metal level $( \pm$ SEM) in surface water of Lagos lagoon wetlands (mg/L)

\begin{tabular}{|c|c|c|c|c|c|c|c|}
\hline $\mathbf{S} / \mathbf{N}$ & $\begin{array}{c}\text { Sampling } \\
\text { points }\end{array}$ & $\mathbf{P b}$ & $\mathbf{C d}$ & $\mathrm{Cr}$ & $\mathrm{Ni}$ & $\mathbf{C u}$ & $\mathbf{Z n}$ \\
\hline 1 & S 01 & $0.84 \pm 0.04$ & $0.01 \pm 0.00$ & $0.10 \pm 0.00$ & $0.14 \pm 0.03$ & $0.85 \pm 0.06$ & $0.17 \pm 0.01$ \\
\hline 2 & S 02 & $0.91 \pm 0.04$ & $0.02 \pm 0.00$ & $0.16 \pm 0.02$ & $0.12 \pm 0.02$ & $0.63 \pm 0.04$ & $0.20 \pm 0.01$ \\
\hline 3 & $\mathrm{~S} 03$ & $0.45 \pm 0.05$ & $0.08 \pm 0.01$ & $0.21 \pm 0.02$ & $0.09 \pm 0.00$ & $0.86 \pm 0.06$ & $0.40 \pm 0.03$ \\
\hline 4 & S 04 & $0.65 \pm 0.03$ & $0.06 \pm 0.00$ & $0.73 \pm 0.03$ & $0.07 \pm 0.00$ & $1.02 \pm 0.00$ & $0.19 \pm 0.02$ \\
\hline 5 & S 05 & $0.74 \pm 0.03$ & $0.15 \pm 0.01$ & $0.67 \pm 0.04$ & $0.05 \pm 0.00$ & $0.91 \pm 0.06$ & $0.38 \pm 0.03$ \\
\hline 6 & S 06 & $0.23 \pm 0.02$ & $0.01 \pm 0.01$ & $0.12 \pm 0.00$ & $0.10 \pm 0.00$ & $0.78 \pm 0.05$ & $0.60 \pm 0.03$ \\
\hline 7 & S 07 & $0.23 \pm 0.03$ & $0.01 \pm 0.01$ & $0.18 \pm 0.01$ & $0.11 \pm 0.02$ & $0.65 \pm 0.07$ & $0.54 \pm 0.02$ \\
\hline 8 & S 08 & $0.10 \pm 0.00$ & $0.01 \pm 0.02$ & $0.23 \pm 0.02$ & $0.19 \pm 0.04$ & $0.72 \pm 0.04$ & $0.32 \pm 0.02$ \\
\hline 9 & S 09 & $0.05 \pm 0.00$ & $0.01 \pm 0.02$ & $0.59 \pm 0.03$ & $0.21 \pm 0.01$ & $0.83 \pm 0.04$ & $0.21 \pm 0.00$ \\
\hline 10 & S 10 & $0.09 \pm 0.00$ & $0.02 \pm 0.01$ & $0.90 \pm 0.04$ & $0.14 \pm 0.06$ & $0.92 \pm 0.07$ & $0.15 \pm 0.00$ \\
\hline 11 & S 11 & $0.10 \pm 0.01$ & $0.01 \pm 0.01$ & $1.07 \pm 0.00$ & $0.09 \pm 0.01$ & $0.75 \pm 0.04$ & $10.28 \pm 0.02$ \\
\hline 12 & S 12 & $0.15 \pm 0.01$ & $0.00 \pm 0.00$ & $0.90 \pm 0.03$ & $0.11 \pm 0.00$ & $0.79 \pm 0.04$ & $2.31 \pm 0.02$ \\
\hline 13 & S 13 & $0.09 \pm 0.01$ & $0.00 \pm 0.00$ & $0.87 \pm 0.02$ & $0.30 \pm 0.07$ & $0.85 \pm 0.03$ & $0.26 \pm 0.03$ \\
\hline 14 & S 14 & $0.15 \pm 0.00$ & $0.00 \pm 0.00$ & $0.94 \pm 0.04$ & $0.22 \pm 0.03$ & $0.76 \pm 0.04$ & $0.34 \pm 0.03$ \\
\hline 15 & S 15 & $0.19 \pm 0.01$ & $0.00 \pm 0.00$ & $0.88 \pm 0.03$ & $0.19 \pm 0.02$ & $0.69 \pm 0.05$ & $0.29 \pm 0.02$ \\
\hline 16 & S 16 & $0.68 \pm 0.02$ & $0.17 \pm 0.02$ & $0.15 \pm 0.00$ & $0.01 \pm 0.00$ & $0.96 \pm 0.04$ & $0.19 \pm 0.01$ \\
\hline 17 & S 17 & $0.75 \pm 0.03$ & $0.09 \pm 0.01$ & $0.20 \pm 0.02$ & $0.00 \pm 0.00$ & $0.26 \pm 0.05$ & $0.32 \pm 0.02$ \\
\hline 18 & S 18 & $0.88 \pm 0.02$ & $0.15 \pm 0.02$ & $0.35 \pm 0.02$ & $0.05 \pm 0.01$ & $0.21 \pm 0.01$ & $0.72 \pm 0.19$ \\
\hline 19 & S 19 & $0.57 \pm 0.02$ & $0.12 \pm 0.02$ & $0.60 \pm 0.05$ & $0.03 \pm 0.00$ & $0.24 \pm 0.04$ & $0.80 \pm 0.32$ \\
\hline 20 & S 20 & $0.45 \pm 0.03$ & $0.09 \pm 0.01$ & $0.52 \pm 0.02$ & $0.10 \pm 0.01$ & $0.35 \pm 0.07$ & $0.67 \pm 0.03$ \\
\hline 21 & S 21 & $0.03 \pm 0.01$ & $0.05 \pm 0.02$ & $0.97 \pm 0.02$ & $0.39 \pm 0.09$ & $1.11 \pm 0.01$ & $3.88 \pm 0.04$ \\
\hline 22 & S 22 & $0.01 \pm 0.01$ & $0.03 \pm 0.00$ & $1.05 \pm 0.00$ & $0.42 \pm 0.03$ & $1.05 \pm 0.00$ & $4.01 \pm 0.00$ \\
\hline 23 & S 23 & $0.06 \pm 0.02$ & $0.05 \pm 0.00$ & $1.15 \pm 0.01$ & $0.34 \pm 0.06$ & $0.92 \pm 0.07$ & $1.12 \pm 0.01$ \\
\hline 24 & S 24 & $0.03 \pm 0.01$ & $0.12 \pm 0.02$ & $0.78 \pm 0.03$ & $0.21 \pm 0.03$ & $0.88 \pm 0.04$ & $0.86 \pm 0.02$ \\
\hline 25 & S 25 & $0.21 \pm 0.01$ & $0.11 \pm 0.01$ & $0.55 \pm 0.03$ & $0.15 \pm 0.03$ & $0.76 \pm 0.04$ & $0.65 \pm 0.03$ \\
\hline 26 & S 26 & $0.01 \pm 0.00$ & $0.25 \pm 0.03$ & $0.05 \pm 0.00$ & $0.52 \pm 0.03$ & $0.65 \pm 0.04$ & $0.89 \pm 0.04$ \\
\hline 27 & S 27 & $0.01 \pm 0.00$ & $0.31 \pm 0.02$ & $0.23 \pm 0.03$ & $0.45 \pm 0.06$ & $0.60 \pm 0.05$ & $0.34 \pm 0.03$ \\
\hline 28 & S 28 & $0.15 \pm 0.01$ & $0.18 \pm 0.02$ & $0.77 \pm 0.02$ & $0.39 \pm 0.04$ & $0.50 \pm 0.04$ & $6.33 \pm 0.03$ \\
\hline 29 & S 29 & $0.09 \pm 0.00$ & $0.21 \pm 0.01$ & $0.84 \pm 0.04$ & $0.36 \pm 0.07$ & $0.32 \pm 0.32$ & $0.19 \pm 0.01$ \\
\hline 30 & S 30 & $0.07 \pm 0.00$ & $0.29 \pm 0.03$ & $0.34 \pm 0.02$ & $0.32 \pm 0.03$ & $0.49 \pm 0.04$ & $0.42 \pm 0.03$ \\
\hline
\end{tabular}

Heavy Metals in plants species parts: The overall $\mathrm{Pb}$, $\mathrm{Cd}, \mathrm{Cr} \mathrm{Ni}, \mathrm{Cu}$, and $\mathrm{Zn}$ contents in the above and below ground portions of the plants studied have been provided in Table 3. In this study, it is clearly evident from the median values of each metal that the shoots and roots of individual plants accumulated metals in the order: $\mathrm{Zn}>\mathrm{Cu}>\mathrm{Pb}>\mathrm{Cr}>\mathrm{Ni}>\mathrm{Cd}$. Heavy metals concentration in the shoot and root of sampled plants showed varying accumulation and translocation values. This varying trend is similar among the sampled plants. Ipomea aquatica had the highest concentration of $\mathrm{Pb}$ in its shoot $(1.12 \mathrm{mg} / \mathrm{kg})$ while Ludwigia adscendens had the least $(1.12 \mathrm{mg} / \mathrm{kg})$ in its shoot. $\mathrm{Pb}$ level in the roots was highest in Eichonia crassipes $(5.69 \mathrm{mg} / \mathrm{kg}$ ) and least was in the roots of Ludwigia adscendens $(0.15 \mathrm{mg} / \mathrm{kg})$. All the plants harvested for this study were healthy and did not show any toxicity symptoms, however, excess $\mathrm{Pb}$ in plants had been reported to inhibit growth while $\mathrm{Cd}$ can inhibit photosynthesis and mineral assimilation causing leaf chlorosis, necrosis, and abscission (Adesuyi et al., 2015a; Jha et al., 2016). Ipomoea involucrata also had the highest level of $\mathrm{Cd}$ in its shoots $(0.45 \mathrm{mg} / \mathrm{kg})$ while the shoots of Phragmites australis, Eichonia crassipes, Ludwigia adscendens, and Phragmites australis all had the least $\mathrm{Cd}$ level $(0.01 \mathrm{mg} / \mathrm{kg})$ in their shoots. But the root of Cyperus rotundus had the highest concentration of $\mathrm{Cd}(1.50$ $\mathrm{mg} / \mathrm{kg}$ ) while the root of Pistia stratiotes had the lowest concentration $(0.01 \mathrm{mg} / \mathrm{kg})$. This lagoon wetlands foster plants and animals that contribute to food webs and are eaten by humans. Cd uptake in organisms is strongly affected by the $\mathrm{Zn}$ concentrations in the substrate (Brzóska and Moniuszko-Jakoniuk, 2001; Jacob et al., 2013), because both metals compete for the same uptake mechanisms. As a result, higher uptake and translocation in plants are observed when the $\mathrm{Cd} / \mathrm{Zn}$ ratio is relatively high (Chaney, 2010).

Table 3: Heavy metals in wetlands plants species parts $(\mathrm{mg} / \mathrm{kg})$ 


\begin{tabular}{|c|c|c|c|c|c|c|c|c|}
\hline $\begin{array}{l}\text { Plants } \\
\text { species }\end{array}$ & $\begin{array}{l}\text { ampling } \\
\text { points }\end{array}$ & Part & $\mathrm{Pb}$ & $\mathrm{Cd}$ & $\mathrm{Cr}$ & $\mathbf{N i}$ & $\mathrm{Cu}$ & Zn \\
\hline Ludwigia & \multirow[t]{2}{*}{1} & Shoot & 0.21 & 0.01 & 0.35 & 0.01 & 1.88 & 2.65 \\
\hline \multirow{7}{*}{ adscenden } & & Root & 2.05 & 0.01 & 0.89 & 0.01 & 2.95 & 4.01 \\
\hline & \multirow[t]{2}{*}{3} & Shoot & 0.05 & 0.01 & 0.18 & 0.02 & 1.34 & 0.63 \\
\hline & & Rot & 0.15 & 0.03 & 0.60 & 0.05 & 1.50 & 1.10 \\
\hline & \multirow[t]{2}{*}{9} & Shoot & 1.01 & 0.09 & 0.08 & 0.16 & 1.45 & 0.67 \\
\hline & & Rot & 3.58 & 0.35 & 0.90 & 0.51 & 2.01 & 2.42 \\
\hline & \multirow[t]{2}{*}{13} & Shoot & 0.31 & 0.18 & 0.11 & 0.14 & 0.62 & 1.15 \\
\hline & & Root & 0.75 & 0.72 & 0.67 & 0.60 & 1.30 & 2.54 \\
\hline \multirow{6}{*}{$\begin{array}{l}\text { Eichoria } \\
\text { crassipes }\end{array}$} & \multirow[t]{2}{*}{2} & Shoot & 0.09 & 0.01 & 0.21 & 0.01 & 2.09 & 0.95 \\
\hline & & Root & 1.19 & 0.05 & 0.75 & 0.02 & 3.31 & 1.31 \\
\hline & \multirow[t]{2}{*}{26} & Shoot & 1.62 & 0.19 & 0.42 & 0.16 & 4.21 & 3.65 \\
\hline & & Rot & 5.69 & 0.65 & 0.55 & 0.30 & 7.56 & 4.87 \\
\hline & \multirow[t]{2}{*}{29} & Shoot & 0.96 & 0.32 & 0.19 & 0.56 & 2.97 & 3.23 \\
\hline & & Root & 3.65 & 1.21 & 0.65 & 1.62 & 5.63 & 4.89 \\
\hline Althemathera & \multirow[t]{2}{*}{6} & Shoot & 0.09 & 0.03 & 0.04 & 0.01 & 0.56 & 0.98 \\
\hline \multirow{9}{*}{ philoxerrides } & & Root & 0.50 & 0.15 & 0.18 & 0.03 & 1.02 & 1.23 \\
\hline & \multirow[t]{2}{*}{10} & Shoot & 0.10 & 0.05 & 0.22 & 0.05 & 0.76 & 0.23 \\
\hline & & $R \infty t$ & 0.35 & 0.20 & 0.97 & 0.30 & 1.05 & 1.52 \\
\hline & \multirow[t]{2}{*}{14} & Shoot & 0.89 & 0.38 & 0.87 & 1.03 & 1.45 & 1.89 \\
\hline & & $R \infty t$ & 2.50 & 1.05 & 2.50 & 0.10 & 2.56 & 2.86 \\
\hline & \multirow[t]{2}{*}{19} & Shoot & 1.10 & 0.07 & 0.35 & 0.08 & 2.21 & 4.64 \\
\hline & & Rot & 4.21 & 0.25 & 0.28 & 0.19 & 4.10 & 10.55 \\
\hline & 21 & Shoot & 0.12 & 0.08 & 0.21 & 0.07 & 2.32 & 1.56 \\
\hline & & Root & 0.24 & 0.22 & 0.15 & 0.16 & 4.04 & 2.87 \\
\hline Commelina & 7 & Shoot & 0.24 & 0.21 & 2.23 & 0.18 & 2.01 & 1.96 \\
\hline benghalen is & & Rot & 1.78 & 1.12 & 5.41 & 0.67 & 2.98 & 14.25 \\
\hline & 11 & Shoot & 0.19 & 0.23 & 1.16 & 0.21 & 0.56 & 2.02 \\
\hline & & Rot & 1.60 & 1.19 & 3.52 & 0.76 & 1.00 & 4.21 \\
\hline & 20 & Shoot & 0.97 & 0.10 & 0.30 & 0.11 & 2.29 & 1.29 \\
\hline & & Root & 1.81 & 0.30 & 0.25 & 0.25 & 3.55 & 2.45 \\
\hline Enhudra & 8 & Shoot & 0.31 & 0.10 & 0.92 & 0.22 & 1.54 & 1.72 \\
\hline fluctuar & & Rot & 2.30 & 0.94 & 3.53 & 1.00 & 2.66 & 3.35 \\
\hline & 18 & Shoot & 0.13 & 0.01 & 0.08 & 0.05 & 2.08 & 0.99 \\
\hline & & Rot & 0.39 & 0.05 & 0.10 & 0.10 & 2.67 & 1.25 \\
\hline Ipomea & 15 & Shoot & 1.12 & 0.21 & 0.24 & 0.09 & 0.23 & 2.10 \\
\hline aquatica & & $R \infty t$ & 3.33 & 0.65 & 0.88 & 0.30 & 0.77 & 5.18 \\
\hline & 23 & Shoot & 1.01 & 0.32 & 0.36 & 0.18 & 2.19 & 5.21 \\
\hline & & Root & 3.28 & 0.89 & 1.00 & 0.30 & 6.56 & 14.54 \\
\hline & 28 & Shoot & 0.21 & 0.21 & 0.26 & 0.11 & 1.54 & 2.12 \\
\hline & & Rot & 0.85 & 0.78 & 1.02 & 0.30 & 3.56 & 4.40 \\
\hline Nymphasa & 25 & Shoot & 0.10 & 0.02 & 0.08 & 0.12 & 1.26 & 1.54 \\
\hline lotus & & Rot & 0.25 & 0.15 & 0.10 & 0.20 & 3.54 & 1.89 \\
\hline & 30 & Shoot & 1.09 & 0.18 & 0.12 & 1.86 & 1.78 & 10.43 \\
\hline & & Root & 1.21 & 0.29 & 0.40 & 1.11 & 3.89 & 15.64 \\
\hline Cyperus & 17 & Shoot & 0.16 & 0.01 & 0.06 & 0.01 & 1.98 & 2.56 \\
\hline rotundus $L$ & & Root & 0.30 & 0.05 & 0.21 & 0.05 & 5.50 & 4.01 \\
\hline & 27 & Shoot & 0.23 & 0.12 & 0.28 & 0.05 & 3.19 & 3.51 \\
\hline & & $R \infty t$ & 1.03 & 1.50 & 0.98 & 0.24 & 4.62 & 4.78 \\
\hline Cyperus & 24 & Shoot & 0.21 & 0.05 & 0.32 & 0.05 & 1.98 & 1.98 \\
\hline articulata & & Rot & 1.08 & 0.73 & 0.64 & 0.14 & 4.44 & 3.12 \\
\hline Sagittaria & 5 & Shoot & 0.30 & 0.10 & 1.95 & 0.09 & 0.34 & 2.27 \\
\hline sagittifolia & & $R \infty t$ & 1.75 & 1.12 & 4.12 & 0.42 & 0.69 & 4.15 \\
\hline Phragmites & 4 & Shoot & 0.49 & 0.01 & 1.56 & 0.04 & 1.54 & 4.43 \\
\hline aus tralis & & Root & 1.80 & 0.03 & 2.97 & 0.12 & 1.70 & 7.52 \\
\hline Ipomoea & 12 & Shoot & 0.23 & 0.45 & 0.78 & 0.19 & 0.15 & 1.56 \\
\hline inolucrata & & Rot & 1.05 & 1.01 & 1.20 & 0.68 & 0.84 & 2.19 \\
\hline Pistia & 16 & Shoot & 0.12 & 0.01 & 0.25 & 0.10 & 1.97 & 1.54 \\
\hline stratiates & & Root & 0.42 & 0.02 & 0.10 & 0.32 & 3.00 & 5.75 \\
\hline Paspalion & 22 & Shoot & 0.22 & 0.28 & 0.21 & 0.05 & 3.69 & 8.95 \\
\hline vaginatuon & & Root & 1.21 & 1.01 & 0.71 & 0.20 & 12.32 & 16.54 \\
\hline
\end{tabular}

The highest level of $\mathrm{Cr}$ in shoot (2.23 $\mathrm{mg} / \mathrm{kg})$ and root $(5.41 \mathrm{mg} / \mathrm{kg})$ was observed in Commelina benghalensis while $\mathrm{Cr}$ concentration is lowest in the shoot $(0.04 \mathrm{mg} / \mathrm{kg})$ and root $(0.18$ $\mathrm{mg} / \mathrm{kg}$ ) of Althernathera philoxerrides. Nymphaea lotus had the highest concentration both in its shoot $(1.86 \mathrm{mg} / \mathrm{kg})$ and its root $(1.11$ $\mathrm{mg} / \mathrm{kg}$ ) while Ludwigia adscendens and Eichonia crassipes both had the lowest shoot concentration (0.01 $\mathrm{mg} / \mathrm{kg}$ ). Ludwigia adscendens had the lowest concentration of $\mathrm{Ni}$ in its root $(0.01 \mathrm{mg} / \mathrm{kg})$. The highest shoot concentration of $\mathrm{Cu}(4.21 \mathrm{mg} / \mathrm{kg})$ was observed in Eichonia crassipes while Ipomea aquatica had the lowest concentration in its shoot $(0.23$ $\mathrm{mg} / \mathrm{kg}$ ). Paspalum vaginatum's root had the highest $\mathrm{Cu}$ concentration $(12.32 \mathrm{mg} / \mathrm{kg})$ while lowest concentration of $\mathrm{Cu}$ was observed in the root of Sagittaria sagittifolia ( 0.69 $\mathrm{mg} / \mathrm{kg}$ ). The highest $\mathrm{Zn}$ concentration in plant shoots was observed in Nymphaea lotus $(10.43 \mathrm{mg} / \mathrm{kg}$ ) while Althernathera philoxerrides had the lowest $\mathrm{Zn}$ concentration $(0.23 \mathrm{mg} / \mathrm{kg})$ in its shoot. Paspalum vaginatum had the highest concentration of $\mathrm{Zn}$ in its root $(16.54 \mathrm{mg} / \mathrm{kg})$ while Ludwigia adscendens had the lowest concentration $(1.10 \mathrm{mg} / \mathrm{kg})$. In this study, the general trend of higher concentration of heavy metals in plants roots than in shoots was obvious which seems to indicate bioaccumulation. Heavy metal species can have different bioavailability to wetlands plants because of physiological differences with respect to uptake sites and uptake mechanisms (Jha et al., 2016). Soil geochemistry influences metal speciation in soils and sediments while plant physiology and genotypic differences control the ability of plants to accumulate plant-available forms of metals (Brook and Robinson, 1998). 
The bioaccumulation factors for shoots (BAF) and the transfer factors (TF) have also been provided to understand their accumulation potential (Table 4). Bio-accumulation Factor (BAF) is used to quantify the toxic element accumulation efficiency in plants by comparing the concentration in the plant part and an external medium (Rezvaniland Zaefarian, 2011). BAF has been categorised as: <1 excluder, 1 - 10 accumulator and $>10$ hyperaccumulator (Jha et al., 2016). It can be seen from table 4 that the extent of accumulation of heavy metals by individual plants differed not only with the type of metal but also with the sampling points. For this study, $\mathrm{Zn}$ was the widely most accumulated in the plants, followed by $\mathrm{Cu}, \mathrm{Ni}$, $\mathrm{Pb}, \mathrm{Cr}$ and the least was $\mathrm{Cd}$. This is similar with the findings reported by Zhang et al. (2010) that the increasing accumulation of $\mathrm{Zn}$ in wetlands plant is positively correlated with the increasing soil or sediment metal concentrations. The plants bioaccumulation of $\mathrm{Zn}$ and $\mathrm{Cd}$ were highest and lowest, respectively, as also in the plants of this study. For, our hyper accumulating plants species, Ludwigia adscendens $(\mathrm{Cd})$, P. australis $(\mathrm{Cr})$, I. involucrata $(\mathrm{Cd})$, C. benghalensis $(\mathrm{Cd}), S$. sagittifolia $(\mathrm{Cd}$ and $\mathrm{Cr}), E$. fluctuans $(\mathrm{Cd}$ and $\mathrm{Cr}$ ) and A. philoxeroides $(\mathrm{Cd})$ satisfy the criterion of BAF greater than 10. A plant's ability to translocate metals from the roots to the shoots is measured using the translocation factor (TF), and TF greater than $1(>1)$ signifies that the plant effectively translocate heavy metals from roots to the shoots (Rezvaniland Zaefarian, 2011). Transfer factors for most of the plants species were less than 1 , indicating that metals accumulated by these plants were largely retained in the roots. High accumulation of heavy metals in roots and low translocation in shoots may indicate appropriateness of a plant species for phytostabilisation (Archer and Caiwell, 2004).This mechanism of partitioning is a common strategy of plants to concentrate harmful ions in the roots in order to prevent toxicity to the leaves which is the site of photosynthesis and other metabolic activities (Jha et al., 2016). A. philoxerrides had translocation factor greater than one for $\mathrm{Ni}$ (10.30), while for $\mathrm{Cr}$ was 1.25 and 1.40. It is clearly evident from this study that $A$. philoxeroides were potential accumulator of $\mathrm{Ni}$ and $\mathrm{Cr}$ $(\mathrm{TF}>1)$ in three of the sampling points across the wetlands. $N$. lotus, $C$. benghalensis, and $P$. stratiotes $(\mathrm{TF}>1)$ also exhibited considerable translocation potential for $\mathrm{Ni}$ (1.68), $\mathrm{Cr}$ (1.21) and $\mathrm{Cr}$ (2.50) respectively. This study corroborates the results of Jha et al. (2016) who suggested that A. philoxeroides shows considerable promise not only as an efficient accumulator of $\mathrm{Pb}$ and $\mathrm{Cd}$ in its roots but its ability to rapidly uptake heavy metals even at very low ambient levels could also make it an efficient indicator of the aquatic ecosystem quality.

Table 4: Bioaccumulation factor and Translocation factor

\begin{tabular}{|c|c|c|c|c|c|c|c|c|c|c|c|c|}
\hline \multirow[t]{2}{*}{ Plants species } & \multicolumn{2}{|c|}{$\mathrm{Pb}$} & \multicolumn{2}{|c|}{$\mathrm{Cd}$} & \multicolumn{2}{|r|}{$\mathrm{Cr}$} & \multicolumn{2}{|c|}{ Ni } & \multicolumn{2}{|c|}{$\mathrm{Cu}$} & \multicolumn{2}{|c|}{$\mathrm{Zn}$} \\
\hline & BAFs & TF & BAFs & TF & BAFs & T F & BAFs & TF & BAFs & TF & BAFs & TF \\
\hline \multirow[t]{4}{*}{ L. actcenclen } & 0.17 & 0.10 & 1.00 & 1.00 & 0.32 & 0.39 & 1.00 & 1.00 & 0.74 & 0.64 & 0.64 & 0.66 \\
\hline & 0.05 & 0.33 & 1.00 & 0.33 & 0.44 & 0.30 & $2.00=$ & 0.40 & 0.49 & 0.89 & 0.59 & 0.57 \\
\hline & $2.41=$ & 0.28 & $3.00=$ & 0.26 & 0.17 & 0.09 & $2.29=$ & 0.31 & 0.94 & 0.72 & 0.66 & 0.28 \\
\hline & 0.16 & 0.41 & $18.00=$ & 0.25 & 0.09 & 0.16 & 0.21 & 0.23 & 0.69 & 0.48 & 0.79 & 0.45 \\
\hline \multirow[t]{3}{*}{ E. crass pipes } & 0.06 & 0.08 & 1.00 & 0.2 & 0.42 & 0.28 & 1.00 & 0.50 & 0.69 & 0.63 & 0.87 & 0.72 \\
\hline & $1.51=$ & 0.28 & 0.34 & 0.29 & 0.75 & 0.76 & 0.17 & 0.53 & $4.73=$ & 0.56 & $2.52=$ & 0.75 \\
\hline & $1.48=$ & 0.26 & 0.89 & 0.26 & 0.29 & 0.29 & $1.27=$ & 0.35 & $3.26=$ & 0.53 & $4.14=$ & 0.66 \\
\hline \multirow[t]{5}{*}{ A. philoxemide } & $1.80=$ & 0.18 & 0.25 & 0.20 & 0.05 & 0.22 & 0.20 & 0.33 & 0.35 & 0.55 & 1.40 & 0.79 \\
\hline & 0.29 & 0.29 & 0.09 & 0.25 & 0.39 & 0.23 & 0.29 & 0.17 & 0.41 & 0.72 & 0.09 & 0.15 \\
\hline & 0.49 & 0.36 & $18.00^{h}$ & 0.36 & 0.83 & 0.35 & $1.91=$ & $10.30 *$ & $3.15=$ & 0.57 & 0.39 & 0.66 \\
\hline & $1.96=$ & 0.26 & 0.26 & 0.28 & 0.09 & $1.25 *$ & $8.00=$ & 0.42 & $1.86=$ & 0.54 & $13.7=$ & 0.44 \\
\hline & 0.02 & 0.50 & 0.05 & 0.36 & 0.03 & $1.40^{*}$ & 0.70 & 0.44 & 0.73 & 0.58 & 0.10 & 0.54 \\
\hline \multirow[t]{3}{*}{ C. benghalensis } & $2.00=$ & 0.13 & 0.46 & 0.19 & $3.32=$ & 0.41 & 0.95 & 0.27 & $1.28=$ & 0.68 & $2.23=$ & 0.14 \\
\hline & 0.09 & 0.12 & $23.0^{\mathrm{h}}$ & 0.19 & 0.94 & 0.33 & $1.05=$ & 0.28 & 0.58 & 0.56 & 0.79 & 0.48 \\
\hline & 0.59 & 0.54 & 0.35 & 0.33 & 0.88 & $1.20^{*}$ & 0.73 & 0.44 & $1.42=$ & 0.65 & $2.69=$ & 0.53 \\
\hline \multirow[t]{2}{*}{ E. fluctuan } & 0.53 & 0.13 & $1.70=$ & 0.11 & 1.70 & 0.26 & $2.20=$ & 0.22 & $1.22=$ & 0.58 & $172^{=}$ & 0.51 \\
\hline & 0.13 & 0.33 & 0.06 & 0.20 & 0.02 & 0.80 & $1.67=$ & 0.50 & $1.90=$ & 0.78 & 1.32 & 0.79 \\
\hline \multirow[t]{3}{*}{ I. aquatica } & 0.50 & 0.34 & 2.10 & 0.32 & 0.05 & 0.27 & 0.14 & 0.30 & 0.26 & 0.29 & 0.79 & 0.41 \\
\hline & 0.28 & 0.31 & 2.10 & 0.32 & 0.09 & 0.36 & 0.17 & 0.60 & 0.77 & 0.33 & $2.49=$ & 0.36 \\
\hline & 0.24 & 0.25 & 1.11 & 0.27 & 0.44 & 0.25 & 0.21 & 0.37 & $1.47=$ & 0.43 & $3.16=$ & 0.49 \\
\hline \multirow[t]{2}{*}{ N. latus } & 0.03 & 0.40 & 0.03 & 0.13 & 0.08 & 0.80 & 0.13 & 0.60 & 0.57 & 0.36 & 0.59 & 0.81 \\
\hline & $1.15=$ & 0.90 & 0.45 & 0.62 & 0.13 & 0.30 & $6.00=$ & $1.68 *$ & $1.62=$ & 0.46 & $8.77=$ & 0.67 \\
\hline \multirow[t]{2}{*}{ C. rotuondus } & 0.30 & 0.53 & 0.07 & 0.20 & 0.01 & 0.29 & 1.00 & 0.20 & $1.20=$ & 0.36 & $2.53=$ & 0.64 \\
\hline & 0.24 & 0.22 & 0.30 & 0.08 & 0.42 & 0.29 & 0.08 & 0.21 & $3.29=$ & 0.69 & $4.03=$ & 0.73 \\
\hline C. articulata & 0.07 & 0.19 & 0.03 & 0.07 & 0.10 & 0.50 & 0.06 & 0.36 & $1.28=$ & 0.45 & $1.57=$ & 0.63 \\
\hline S. sagittifolia & 0.39 & 0.17 & $10.0^{\mathrm{h}}$ & 0.09 & $11.47^{\mathrm{h}}$ & 0.47 & $3.00=$ & 0.21 & 0.09 & 0.49 & $2.37=$ & 0.55 \\
\hline$P$. australis & 0.52 & 0.27 & 1.00 & 0.33 & $12.00^{k}$ & 0.53 & $4.00=$ & 0.33 & 0.49 & 0.91 & $5.68=$ & 0.59 \\
\hline I. involuarata & 0.12 & 0.22 & $15.00^{k}$ & 0.45 & 0.20 & 0.65 & 0.59 & 0.28 & 0.27 & 0.18 & 0.19 & 0.71 \\
\hline P. stratiotes & 0.17 & 0.29 & 0.05 & 0.50 & 0.74 & $2.50^{*}$ & $2.00=$ & 0.31 & $2.26=$ & 0.66 & $1.06=$ & 0.27 \\
\hline$P$. vagination & 0.03 & 0.18 & 0.14 & 0.28 & 0.05 & 0.29 & 0.06 & 0.25 & $1.25=$ & 0.29 & $2.45=$ & 0.54 \\
\hline
\end{tabular}

${ }^{*}$ TF greater than $1,{ }^{a} B A F$ less than $10,{ }^{h} B A F$ greater than 10

Numerous studies have shown $P$. stratiotes to be good Conclusion: This present findings indicated that, accumulators of heavy metals as also observed despite ecological and morphological similarities (Valitutto et al., 2006; Adamu et al., 2015). across the wetlands, these plant species tend to respond differently to exposure to heavy metals and in 
their ability to accumulate and detoxify the various metals. Thus, heavy metals sequestration from the soil to these plants characterized them as metals pollution indicators. The present investigation also revealed that A. philoxeroides, $N$. lotus, $C$. benghalensis, and $P$. stratiotes could be great potential for phytostabilisation and phytoextraction of $\mathrm{Ni}$ and $\mathrm{Cr}$.

Acknowledgment: The authors gratefully acknowledge the Shell Petroleum Development Company (SPDC), Port Harcourt, Rivers State, Nigeria, and University Relations of Shell for the PhD Research Internship and support received by Adeola Alex Adesuyi. Special thanks to the Corporate Environment Department and the EIA team of SPDC especially Temitope Ajibade, Sola Ojesanmi, Belema Ogbangba and Moses Ngwoke. Also special thanks to Mrs Jolaoso Anu for her role during field sampling.

\section{REFERENCES}

Adamu, YU; Tasiu, SI; Salisu MT (2015). The Use of Pistia stratiotes to Remove some Heavy Metals from Romi Stream: A Case Study of Kaduna Refinery and Petrochemical Company Polluted Stream. J. Env. Sci., Toxi. Food Tech, 9(1): 48-51.

Adesuyi, AA; Njoku, KL; Akinola, MO (2015b). Assessment of Heavy metals pollution in soils and vegetation around selected Industries in Lagos, South western Nigeria. Journal of Geoscience and Environment Protection, 3:11-19.

Adesuyi, AA; Nnodu, VC; Njoku, KL; Jolaoso, A (2015a). Nitrate and Phosphate Pollution in Surface Water of Nwaja Creek, Port Harcourt, Niger Delta, Nigeria. International Journal of Geology, Agriculture and Environmental Sciences, 3(5):14-20

Adesuyi, AA; Nnodu, VC; Njoku, KL; Jolaoso, A (2016) Evaluation of Industrial Discharge Point Source Pollution in Ikeja Industrial Estate, Ikeja, Lagos, Nigeria. Unilag Journal of Science, Management and Technology, 4(2):18-29.

Akguc, N; Ozyigit, II; Yasar, U; Leblebici, Z; Yarci, C (2010). Use of Pyracantha coccinea Roem. as a possible biomonitor for the selected heavy metals. Int. J. Environ. Sci. Tech., 7(3):427-434.

Akinola, MO; Njoku, KL; Ekeifo, BE (2008). Determination of lead, cadmium and chromium in the tissue of an economically important plant around a textile industry at Ibeshe, Ikorodu Area of Lagos State Nigeria. Advances in Environmental Biology, 2(1): 25-30.
Amos-Tautua, BMW; Onigbinde, AO; Ere, D (2014). Assessment of some heavy metals and physicochemical properties in surface soils of municipal open waste dumpsite in Yenagoa, Nigeria. African Journal of Environmental Science and Technology, 8(1):41-47.

Archer, MJG; Caiwell, RA (2004). Response of Six Australian Plants Species to Heavy Metal Contamination at an Abandoned Mine Site. Water, Air, and Soil Pollution, 157:257-267.

Armitage, PD; Bowes, MJ; Vincent, HM (2007). Long-term changes in macroinvertebrate communities of a heavy metal polluted stream: The rivernent (Cumbria, UK) after 28 years. River Res., 23:997-1015.

Asibor, G (2009) Wetlands: values, uses and challenges. A Paper presented to the Nigerian Environmental Society at the Petroleum Training Institute, Effurun, $21^{\text {st }}$ November, 2009.

Brook, RR; Robinson, BH (1998). Aquatic Phytoremediation by Accumulator Plants. In: Brook, R.R., Ed., Plants that Hyperaccumulate Heavy Metals: Their Role in Phytoremediation, Microbiology, Archaeology, Mineral Exploration and Phytomining, CABI International, Wallingford, 203-226.

Brzóska, MM; Moniuszko-Jakoniuk, J (2001). Interactions between cadmium and zinc in the organism. Food Chem Toxicol., 39(10):967-80.

Chaney, RL (2010). Cadmium and zinc. In: Hooda PS, editor. Trace Elements in Soils. John Wiley and Sons Ltd; West Sussex, UK. pp. 409-439.

Du Laing, G; Rinklebe, J; Vandecasteele, B; Meers, E; Tack, FM (2009). Trace metal behaviour in estuarine and riverine floodplain soils and sediments: a review. Sci Total Environ., 407:3972-3985.

Estrella-Gómez, N; Mendoza-Cózatl, D; MorenoSánchez, R; González-Mendoza, D; ZapataPérez, O; Martínez-

Hernández, A; Santamaría JM (2009). The Pbhyperaccumulator aquatic fern Salvinia minima Baker, responds to $\mathrm{Pb} 2+$ by increasing phytochelatins via changes in SmPCS expression and in phytochelatin synthase activity. Aquat Toxicol, 91: 320-328.

Fritioff, A; Greger, M (2006). Uptake and distribution of $\mathrm{Zn}, \mathrm{Cu}, \mathrm{Cd}$, and $\mathrm{Pb}$ in an aquatic plant 
Potamogeton natans. Chemosphere, 63: 220227.

Fritioff, A; Kautsky, L; Greger, M (2005). Influence of temperature and salinity on heavy metal uptake by submersed plants. Environ Pollut, 133: 265274.

Gupta, A; Rai, DK; Pandey, RS; Sharma, B (2009). Analysis of some heavy metals in the riverine water, sediments and fish from river Ganges at Allahabad. Environ. Monit. Assess. 157: 449-458.

Jacob, DL; Yellick AH; Kissoon LT; Asgary, A; Wijeyyaratne, DN; Saini-Eidukat, B; Otte, ML (2013). Cadmium and associated metals in soils and sediments of wetlands across the Northern Plains, USA. Environmental pollution, 178: 211219.

Jha, P; Samal, AC; Santra, SC; Dewanji, A (2016). Heavy Metal Accumulation Potential of Some Wetland Plants Growing Naturally in the City of Kolkata, India. American Journal of Plant Sciences, 7, 2112-2137.

Khodadoust, AP; Reddy, KR; Maturi, K (2004). Removal of nickel and phenanthrene from kaolin soil using different extractants. Environmental Engineering Science, (21)6: 691-704.

Klavins, M; Briede, A; Rodinov, V; Kokorite, I; Parele, E; Klavina, I (2000). Heavy metals in rivers of Latvia. Sci. Total Environ. 262: 175183.

Lambert, R; Grant, C; Sauvé, S (2007). Cadmium and zinc in soil solution extracts following the application of phosphate fertilizers. Science of the Total Environment, 378: 293-305.

Matache, ML; Marin, C; Rozylowicz, L; Tudorache, A (2013). Plants accumulating heavy metals in the Danube River wetlands. Journal of Environmental Health Science and Engineering, 11:39.

(Online: https://jehse.biomedcentral.com/articles/10.1186/ 2052-336X-11-39).

Njoku, KL; Akinola, MO; Zinghadina, TO (2013). A study on the spatial distribution of heavy metals in industrial area of Ikorodu, Lagos State Nigeria Journal of Research in Environmental Science and Technology, 2(3): 64-70.
Nwankwoala, HO (2012). Case Studies on Coastal Wetlands and Water Resources in Nigeria. European Journal of Sustainable Development, 1(2): 113-126.

Obiefuna, JN; Nwilo, PC; Atagbaza, AO; Okolie, CJ (2013). Spatial Changes in the Wetlands of Lagos/Lekki Lagoons of Lagos, Nigeria. Journal of Sustainable Development 6(7):123-133.

Oyebande, L; Obot, EO; Bdiliya, HH (2003). An inventory of wetlands in Nigeria. Report prepared for World Conservation Union - IUCN, West African Regional Office, Quagadougou, Burkina Faso.

Pell, A; Marquez, A; Lopez-Sanchez, JF; Rubio, R; Barbero, M; Stegen, S; Queirolo, F; Diaz-Palma, $P$ (2013). Occurrence of arsenic species in algae and freshwater plants of an extreme arid region in northern Chile, the Loa River Basin. Chemosphere, 90: 556-564. 1

Rai, UN; Sinha, S; Tripathi, RD; Chandra, P (1995). Wastewater treatability potential of some aquatic macrophytes: Removal of heavy metals. Ecol Eng. 5: 5-12.

Rezvani, M; Zaefarian, F (2011). Bioaccumulation and translocation factors of cadmium and lead in Aeluropus littoralis. Australian Journal of Agricultural Engineering, 2(4):114-119.

Sakan, SM; Dordevic, DS; Manojlovic, DD; Predrag PS. (2009) Assessment of heavy metal pollutants accumulation in the Tisza river sediments. $J$. Environ. Manag. 90: 3382-3390.

Szefer, P; Geldon, J; Ali, AA; Bawazir A; Sad, M (1997). Distribution and association of trace metals in soft tissue and byssus of mollusc Perna perna from the Gulf of Aden, Yemen. Environ. Int. 23:53-61.

Tam, NFY; Wong, YS (2000). Spatial variation of heavy metals in surface sediments of Hong Kong mangrove swamps. Environ. Pollut. 110:195205.

Valitutto, RS; Sella, SM; Silva-Filho, EV; Pereira, RG; Miekeley, N (2006). Accumulation of metals in macrophytes from water reservoirs of a power supply plant, Rio de Janeiro State, Brazil. Water Air Soil Pollut. 178: 89-102. 
Weis, JS; Weis, P (2004). Metal uptake, transport and release by wetland plants: implications for phytoremediation and restoration. Environ Int. 30: 685-700.

WHO/FAO. (2001). Codex alimentarius commission. Food additives and contaminants. Joint FAO/WHO Food Standards Programme, ALINORM 10/12A. Retrieved from: www.transpaktrading.com/static/pdf/research/ac hemistry/introTofertilizers.pdf.

Wuana, RA; Okieimen, FE (2011). Heavy Metals in Contaminated Soils: A Review of Sources,
Chemistry, Risks and Best Available Strategies for Remediation. ISRN Ecology. http://dx.doi.org/10.5402/2011/402647.

Zhang, H; Cui, B; Xiao, R; Zhao, H (2010). Heavy metals in water, soils and plants in riparian wetlands in the Pearl River Estuary, South China. Procedia Environmental Sciences 2: 1344-1354.

Zhang, X; Yang, F; Luo, C; Wen, S; Zhang, X; Xu, Y (2009). Bioaccumulative characteristics of hexabromocyclododecanes in freshwater species from an electronic waste recycling area in China. Chemosphere, 76(11), 1572-1578. 